\title{
Tax Officer Services and Tax Justice as Preventive Action for Tax Evasion
}

\author{
Eni Suharti and Dewi Rachmania \\ Faculty of Economic and Bussines, University Muhammadiyah Tangerang \\ Email: suharti_eni@yahoo.co.id
}

\begin{abstract}
The research is aimed to analyze of reduction of tax evasion case. Where, this effort by implementation service courtesy of tax officer/Fiscus and fairness of tax regulation for corporate as tax-payer. This matter caused by many tax-fraud that have done by tax-payer (small and big enterprise). Generally, these cases have influence to unperforming tax revenue of government. The tool used in this research is the structure equation model (SEM) with partial least square (PLS) alternative approaches. PLS evaluation model is done by assessing outer model and inner model. That used to test 98 samples (respondent) obtained from the slovin's formula. The result of this reseach show indicates that the implementation of tax officer services/Fiscus have negative impact partially to tax-evasion and fairness of tax regulation has not effect partially on tax evasion.
\end{abstract}

Keywords: Tax officer services, Fairness of Tax, Tax Evasion.

\section{INTRODUCTION}

Tax is one of the most important source of state revenue that is used to finance state expenditure, and it also applies in Indonesia, where most expenditure state's source is from tax. Tax is considered to be the most important source for the state's expenditure, both collected by directorate general of taxes or by directorate general of customs. The amount of general government expenditure in the APBN that must be compiled annually is not supported by government revenue from other sectors beside taxes. This is triggered the government to be able to collect tax as much as they can. But in reality the target of tax revenue set by the government is still not optimal in its achievement, because there are still taxpayers who deliberately do not pay taxes or pay taxes improperly in accordance with applicable laws and regulations.

Tax evasion is an attempt by taxpayers to evade true obligations, and is a violation of taxation laws, for example the taxpayer does not report the actual income which will result in the realization of tax revenue not in accordance with what has been targeted in terms of government policy, there have been various ways to achieve tax revenue realization, including the enactment of tax amnesty until the issuance of the planned reduction of tariffs from 5\% to $1 \%$ for the final UMKM tax rates.

Tax evasion or often referred to as tax evasion, is rife in Indonesia, usually those who carry out tax evasion are corporate taxpayers the big one for example PT. Kaltim Prima Coal, PT. Indosat, PT.Ancora Mining, PT. Bumi Resources and the last Asian Agri Company. 
from some of these companies the types of tax evasion carried out varied.Tax evasion by reducing output PPN and increasing input PPN was carried out by Indosat company to obtain tax refunds and conspire with high state officials in accounting transactions. Meanwhile Kaltim Prima Company carried out tax evasion by reporting overpayment tax returns which should be underpaid or report SPT incorrectly. Bumi resource company did the tax evasion by paying the tax officer. Good tax authorities will certainly provide comfort for taxpayers to fulfill their tax obligations, taxpayers will also be compliant if they feel that the tax paid is used for the benefit of the society in general, but if there is a tendency that the government is not wise in using funds derived from taxes, taxpayers will tend to be motivated to carry out acts of tax evasion.

The indications of taxpayers who carry out tax evasion are if the taxpayer does not submit the tax return, submit the tax return but is incorrect, does not register or misuse NPWP or PKP confirmation, does not deposit the tax collected or witheld and even tries to bribe the tax authorities (waluyo, 2013)

\section{THEORITICAL REVIEW}

Theory of planned behavior (TPB). Theory of planned behavior Stated that in addition to attitudes toward behavior and subjective norms, individuals also considered perceived behavioral control, namely their ability to carry out these actions. (Kurniawati and Toly, 2014). In this study, Theory of planned behavior more emphasis to impact and some potentially aspects from out-control behavior of individual who will gain their specific goal. The model of this theory has some variables, for example: first, background factors and second, behavioral belief. This matter often assumed as positive and negative perspective that have change to action propensity of individuals. Third, normative beliefs that have direct-relation to social environment. Forth, subjective norm where it's describe somebody has a motivation to following others above its idea. Fifth, ability to control individual character or perceived behavioral control. Where individual has a right to choice something to do. Based on above literature. So, Theory of Planned of Behavior have relevant to explain above Tax-payer behavior (individual or enterprise) to fulfill their liabilities and its responsibility.

Theory of fainess. In the theory of fairness tax collection must be in accordance with the objectives of the law in order to achieve justice, the law and the implementation of collection must be fair (Mardiasmo, 2018). Fair in legislation includes taxing in general and evenly, and adjusted to their respective abilities. Things that need to be considered in the joints of justice in tax law are the same treatment to taxpayers, which does not distinguish nationality, both native and foreign, and does not distinguish between religion, political flow, and so on.

However, if there is a conflict of interest between the certainty of tax law and the principle of tax justice, then in this case what must take precedence is legal certainty in order to guarantee the implementation of tax to every taxpayer. Fair if everyone pays taxes according to his ability, so that everyone who has the same income pays the same amount of tax or so-called horizontal equity and people who have income that pays more taxes or are called vertical justice (vertical equity), in Public Finance in Theory and Practice Musgrave also suggested that there are two types of justice principles, namely: Benefit 
Principle, taxpayers (WP) must pay taxes according to the benefits they enjoy from the government, (this approach is called Revenue and Expenditure Approach). Ability to pay Principle, taxpayers (WP) must pay taxes according to their ability to pay (according to income).

This theory of justice is also in line with the theory of pikul style which states that the income pressure of each person is in accordance with the power of paying, so that the tax collected by the state is in accordance with the ability of the taxpayer to pay it.

Tax. In according to the nation book of statute of Republic Indonesia, number 28/2007, act.01, tax defining to contribution through liabilities that must paid by individual or enterprise to the state treasury with no compensation above it. The aim of tax collection will be dedicated to the people prosperity optimally. Tax as the main of revenue resource of a state (Waluyo, 2013). Tax has some functions, for example: budgeter, regular, Allocation, and distribution. From the Tax function it can be said that actually Tax has participated in regulating the economic order of the country, because not all taxes collected by the central government only belong to the central government, (Diaz, 2016) states that there are Taxes administered by the central government will but intended for local governments and there are Taxes administered by the central government but the results are shared with local governments. Types of Central Taxes include PPh, VAT, PPn-BM while Regional Tax is distinguished between Provincial Tax and Regency / city Tax. Tax collection system in Indonesia adopts a Self Assessment System where the taxpayer is given the trust to calculate, deposit and report his own tax obligations, this means that the government gives full trust to the taxpayer. Basically, what has been calculated, deposited and reported by the taxpayer is considered correct by the tax authorities unless the tax authorities have information that identifies that the report is wrong (Diaz, 2016).

Tax Evation. (Pohan, 2015) declare that there are three ways for tax-payer to minimize about tax expenses of them. That is Tax Avoidance, Tax Evasion and Tax Saving. Tax Evasion is one of technique to avoid of tax illegally and un-safe for them. This way is one fraud and fiscal crime that contradict to law and tax regulation. The high-risk of this action shall be judge with severe punishment. Tax Evasion is carried out by taxpayers as an active resistance caused by injustice in the taxation system or because of a gap in a bad taxation system. Tax Evasion can be seen as illegal and unethical and unlawful (Oktaviani et al., 2018). As a result of tax fraud carried out by taxpayers can affect stability in various fields. The financial sector causes an income imbalance, in the economic field it can lead to unfair business competition, scarcity of venture capital because companies that embezzle taxes will certainly cover their profits so as not to be detected by the tax authorities, psychological impacts will be seen from actors who feel fear over Tax embezzlement actions that have been revealed and get sanctions from the act, causing the perpetrators to feel depressed.

Tax officer/Fiscus services. Tax services are public services provided by tax officials or tax authorities to the public registered as taxpayers, this is done to assist taxpayers in fulfilling their tax obligations in accordance with the tax laws. (Hartanti and Nuryatno, 2019). The services begin to greeting every tax-payer until giving socialization to the 
public through direct information and by using some media, include to conduct "Peduli NPWP" parade. The major aim of this action is the quality of services by tax officer should be increase. With high expectation, by this effort continuously people as tax-payer can be realize how necessary of tax and the people have motivated to pay tax and following the right regulation of tax. The excellent service provided by the tax authorities to taxpayers is a tangible manifestation of the tax authorities in optimizing the revenue obtained from taxation, because the goal of excellent service itself is to achieve a high level of voluntary compliance by taxpayers, the achievement of a high level of trust in tax administration and the achievement of productivity tax apparatus so that the tax revenue target can be achieved.

Tax Justice. In tax collection based on the principle of justice, Musgrave revealed that in a fair taxation system, each taxpayer must pay his tax in line with the benefits he enjoys from the government and the tax is charged on the basis of the ability to pay from the taxpayer (Waluyo, 2013). Every citizen must to participate in government programs such as funding and financing. Implementation of citizen participating must according to people capability and proportionally. It's can be done by using Nett-Revenue approach in comparing gained income to facility that received by government. Adam Smith said also that tax collection must to based on equality, certainly, Convenience, economy (Waluyo, 2013). Adolf Wagner states that a fair tax collection is a tax collection that is generally applied to all taxpayers and is charged to all taxpayers who have the ability to pay equally, that one tax rate structure applies to every taxpayer who has the ability to pay taxes. (Pohan, 2017). In tax justice is known by the principle of vertical justice and the principle of horizontal justice where in the renewal of the taxation system in Indonesia the principle of justice is used as a basis in improving and restoring the taxpayers' trust to get justice in taxation. in taxation will be able to influence taxpayers to pay their tax obligations.

Conceptual Framework. Based on the theory and background above, the frame work can be formulated in figure 1 .

Figure 1. Hypothesis Framework of Conceptual (2019)

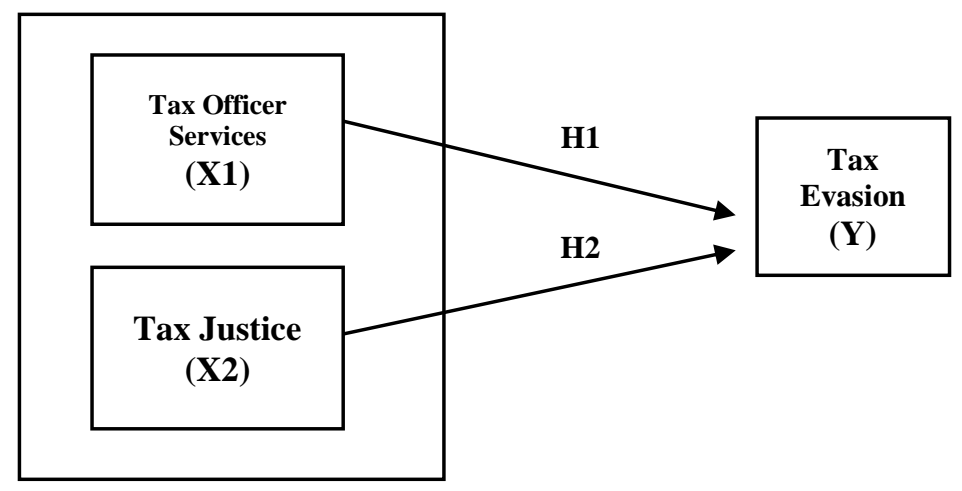

Based on framework above researcher make a hypothesis formulation as following: 
Tax Officer Services. Services that held by tax officer have to equal to standard of quality in build public satisfaction, so that people as tax-payer would have high obedience to pay according the right regulation and target of revenue of tax can be gained optimally. The better quality of service, so tax evasion by tax-payer would be decrease. (Mujiati et al., 2017) and (Rifani et al., 2019) declare that services quality influence to tax-payer perception about tax evasion.

H1: Tax officer services influence to Tax Evasion in listed company at KPP Kosambi Tangerang.

Tax Justice. The more unfair in tax justice system to tax-payer, so tax-payer's obedience to pay would be lower. Its mean that tendency to embezzlement in tax/tax evasion by taxpayer will be higher. According to research by (Kurniati and Toly, 2014) and (Pratiwi and Prabowo, 2019), they said that Tax Justice influence to tax evasion.

H2: Tax justice influence to Tax Evasion in listed at KPP Kosambi Tangerang.

\section{METHODOLOGY}

Research Design. This research use quantitative approach with associative. The chosen data founded by using questioner and measured by using Likert scale, From 1 to 5, Where: 1 = Strongly Disagree, $2=$ Disagree, $3=$ Not Agree, $4=$ Agree, $5=$ Strongly Agree, This research variable consists of Tax Officer Services variable (X1), Tax Justice (X2) and Tax Evasion (Y).

Operational Definition and variable measurement. The used variables in this research are: (1) Endogenous variable, in this research. Tax Evasion is dependent variable. Tax evasion is an action taken by taxpayers to be able to reduce even the burden of tax owed, while (Mardiasmo, 2018), identifying tax evasion as an attempt by taxpayers to ease the tax burden by breaking the law. Some indicators in Tax Evasion, such as: Not reporting and sending SPT (Annual Tax Liabilities Declare), Sending SPT with unconformity by the real, Never make registration on Tax-payer Unique Number (NPWP), Never make statement as PKP, Never paid above tax-collective to state treasury, to bribe the tax officer. (2) Exogenous Variable, in this research Tax Officer services (X1) and tax justice (X2) are independent variable. Some indicators of tax officer services are: Human resource skill and qualities, Knowledge and experience. For Tax Justices indicators are: Optimization the right usage of fund that source from tax, the cheap tariff for people, Wisdom and justice in crafting the nation book of statute in taxing, Unfair of tax officer in application of tax regulation.

Sampling Methods and Criteria of samples. Population in this research are the taxpayer who listed in KPP Pratama Kosambi year 2019 by total population is 3434 respondents. Technique in sample choosing by using probability sampling technique. And using slovin's formulation until founded total sampling 98 tax-payers. Taxpayers used in this study sample are corporate taxpayers that listed in KPP Pratama Kosambi Tangerang.

Data Collection Methods. In this research, used data is primary data. So that used methods in collecting data is observation methods by questioner (Sugiyono, 2017). 
Questioner is one technique for collecting data that conducted by sending the form to the respondents. And respondent expected to fill the form with truthfully.

Analysis Data Methods. In this research, Analysis data methods is quantitative analysis. Quantitative methods is one analysis model that use data in numerical or qualitative in numerical. Data analysis model in this research begin to analyze in statistic description. In this study, to measure whether the model can be continued to be investigated is the outer analysis model consisting of convergent validity test, reliability test, $\mathrm{R}$ square and goodness of fit test, (if the loading factor value is more than 0.7 and AVE value> 0.50 then the instrument was declared valid and could be continued) while the inner model was used to test the research hypothesis. Hypothesis testing is used to test whether the research hypothesis is accepted or rejected, so it can be proven whether the exogenous variables affect the endogenous variables.

\section{THE RESULTS OF STATISTICAL TESTS}

The Result of Statistical Tests. The object in this research are tax-payers who listed in KPP Pratama Kosambi. Totally tax-payers who listed in KPP Pratama Kosambi 3434 objects (individual and enterprise).the sample of this research is 98 samples, In this research have select enterprises object that listed in KPP Pratama Kosambi.

Descriptive Statistic Analysis. In this study, descriptive analysis of research variables is used to provide an overview of Tax Officer Services, Tax Justice and Tax Evasion. Descriptive analysis is done by looking at the average value of each indicator of the research variable. 
Table 1. Descriptive statistic analysis Tax officer services result

\begin{tabular}{|c|c|c|c|c|c|c|c|}
\hline \multicolumn{2}{|c|}{ Indicators: } & \multicolumn{2}{|c|}{ Indicator Correlations } & \multirow{2}{*}{$\begin{array}{l}\text { Raw File } \\
\text { Median }\end{array}$} & \multirow[b]{2}{*}{ Min } & \multirow[b]{2}{*}{ Max } & \multirow[b]{2}{*}{ Standard Deviation } \\
\hline & No. & Missi... & Mean & & & & \\
\hline X1.1 & 1 & 0 & 3.908 & 4.000 & 1.000 & 5.000 & 0.949 \\
\hline $\mathrm{X} 1.2$ & 2 & 0 & 3.908 & 4.000 & 1.000 & 5.000 & 0.858 \\
\hline $\mathrm{X} 1.3$ & 3 & 0 & 3.918 & 4.000 & 1.000 & 5.000 & 0.853 \\
\hline X1.4 & 4 & 0 & 3.969 & 4.000 & 1.000 & 5.000 & 0.863 \\
\hline$X 1.5$ & 5 & 0 & 3.898 & 4.000 & 1.000 & 5.000 & 0.875 \\
\hline $\mathrm{X} 1.6$ & 6 & 0 & 4.000 & 4.000 & 1.000 & 5.000 & 0.795 \\
\hline $\mathrm{X} 1.7$ & 7 & 0 & 3.878 & 4.000 & 1.000 & 5.000 & 0.929 \\
\hline
\end{tabular}

Source: (Data in SmartPLS has been proceed, 2019)

Based on the results of the descriptive analysis in the above table 1, the results of the analysis show that the average value of each indicator in the Tax Officer Service variable agrees (shown from the average value above 3.8) the respondents agree that the Fiscus in serving must have professional quality resources, have adequate knowledge about tax regulations and have sufficient experience. The lowest average value is experienced indicator, this shows that Fiscus' Services are considered not optimal due to lack of experience in education and training, so that there is still a need improvement in education and training.

Table 2. Descriptive statistic analysis Tax Justice result

\begin{tabular}{|r|r|r|r|r|r|r|r|}
\hline \multirow{2}{*}{ Indicators: } & \multicolumn{4}{|l|}{ Indicator Correlations } & Raw File & & \\
\hline & No. & Missi... & Mean & Median & Min & Max & Standard Deviation \\
\hline X2.1 & 8 & 0 & 3.633 & 4.000 & 1.000 & 5.000 & 0.885 \\
\hline X2.2 & 9 & 0 & 3.724 & 4.000 & 1.000 & 5.000 & 0.739 \\
\hline X2.3 & 10 & 0 & 3.704 & 4.000 & 1.000 & 5.000 & 0.745 \\
\hline X2.4 & 11 & 0 & 3.643 & 4.000 & 1.000 & 5.000 & 0.799 \\
\hline X2.5 & 12 & 0 & 3.776 & 4.000 & 2.000 & 5.000 & 0.663 \\
\hline X2.6 & 13 & 0 & 3.684 & 4.000 & 1.000 & 5.000 & 0.790 \\
\hline X2.7 & 14 & 0 & 3.663 & 4.000 & 1.000 & 5.000 & 0.820 \\
\hline X2.8 & 15 & 0 & 3.612 & 4.000 & 1.000 & 5.000 & 0.778 \\
\hline
\end{tabular}

Source: (Data in SmartPLS has been proceed, 2019) 
Descriptive analysis results for the Tax Justice Variables in the table above, show that the average value of each indicator in the Tax justice variable agreed (shown from the average value above 3.6), the respondents agreed that the tax collected was used for public purposes, tariffs The tax imposed must be in accordance with the capabilities and income received by the taxpayers, the law must be based on fairness and equitable treatment of the apparatus of the taxpayers. The lowest average value is shown by the indicator of Tax injustice in carrying out the tax provisions, this shows that Tax Justice is considered not fully felt by the Taxpayer, especially the tax apparatus siding with the small taxpayers, so there is still need to be an improvement in terms of the Tax apparatus Services alignments against small taxpayers.

Table 3. Descriptive statistic analysis Tax Evasion result

\begin{tabular}{|l|l|l|l|l|l|l|l|}
\hline Y.1 & 16 & 0 & 3.418 & 3.000 & 1.000 & 5.000 & 0.832 \\
\hline Y.2 & 17 & 0 & 3.459 & 3.000 & 1.000 & 5.000 & 0.859 \\
\hline Y.3 & 18 & 0 & 3.398 & 3.000 & 1.000 & 5.000 & 0.830 \\
\hline Y.4 & 19 & 0 & 3.418 & 3.000 & 1.000 & 5.000 & 0.844 \\
\hline Y.5 & 20 & 0 & 3.367 & 3.000 & 1.000 & 5.000 & 0.885 \\
\hline Y.6 & 21 & 0 & 3.388 & 3.000 & 1.000 & 5.000 & 0.876 \\
\hline Y.7 & 22 & 0 & 3.388 & 3.000 & 1.000 & 5.000 & 0.888 \\
\hline Y.8 & 23 & 0 & 3.378 & 3.000 & 1.000 & 5.000 & 0.839 \\
\hline
\end{tabular}

Source: (Data in SmartPLS has been proceed, 2019)

Descriptive analysis in the table above, shows that the average value of each indicator in the Tax Evasion variable is less agreeable (shown from the average value below 3.5), the smallest average value is indicated by the indicator not registering / abusing NPWP or strengthening the PKP this shows that the tendency of taxpayers in Tax Evasion is caused by taxpayers not registering themselves or abusing NPWP or PKP confirmation.

Testing Requirements Analysis. In this study, the effect of Fiscus Services, Tax Justice on Tax Evasion will be analyzed using SmartPLS analysis. Based on the operational definition of each research variable, the Fiscus Service variable is measured by 3 indicators through 7 statement items, Tax Justice is measured by 4 indicators through 8 statement items, while Tax Evasion is measured by 4 indicators through 8 statements, so that the PLS model specifications will be estimated in this study seen in the picture below: 
Figure 2. PLS Model Specifications

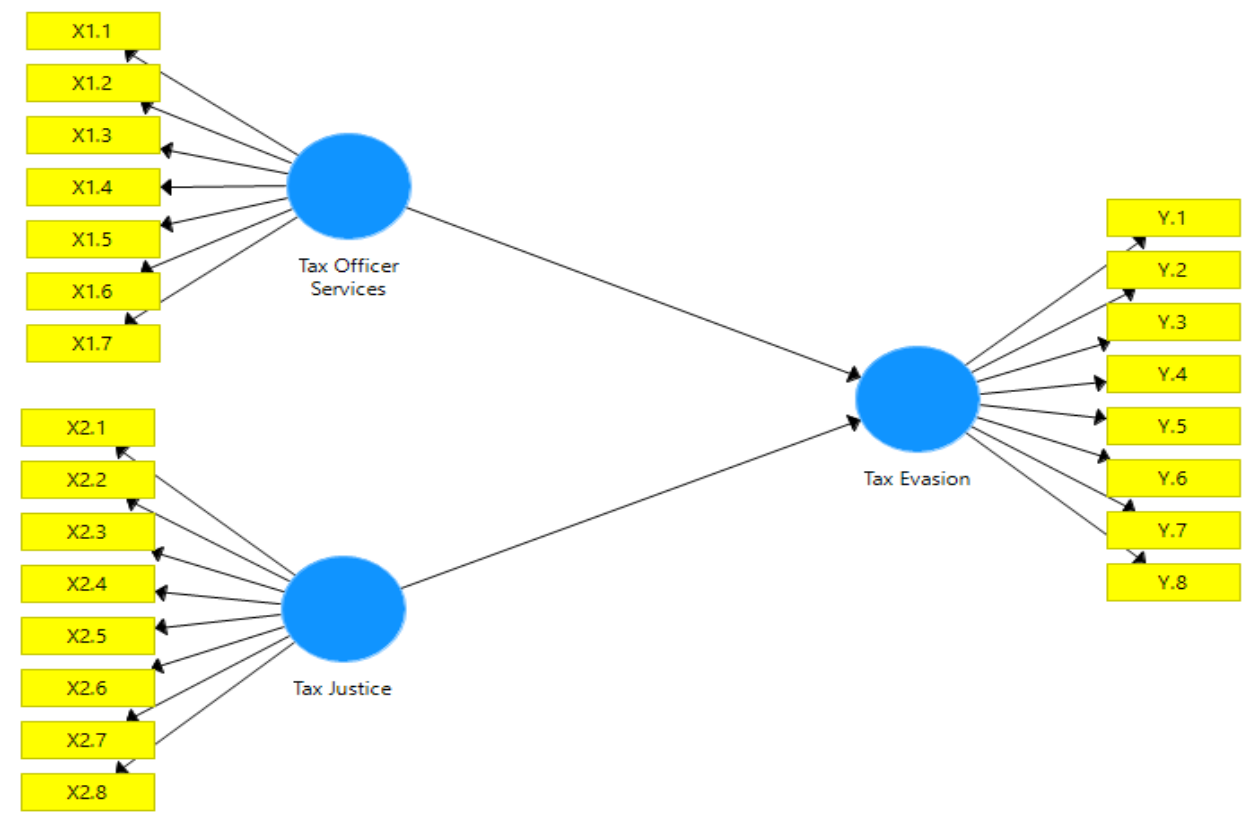

Source: (Data in SmartPLS has been proceed, 2019)

The stages in the PLS analysis include the outer model testing phase, the goodness of fit testing phase and the inner model testing phase.

Outer Model Test. The testing phase of the measurement model includes testing for Convergent Validity, Discriminant Validity and Composite Reliability. The results of the PLS analysis can be used to test the research hypothesis if all the indicators in the PLS model have met the requirements of convergent validity, discriminant validity and composite reliability.

Convergent Validity. Convergent validity test is done by looking at the loading factor value of each indicator to the construct. Because this study is a confirmatory study, the loading factor limit used is 0.7. Besides looking at the loading factor value, construct validity is also assessed from construct AVE value, all indicators in the construct are declared to meet convergent validity if AVE construct is> 0.5 . 
Figure 3. PLS Model Estimation Results - Algorithm

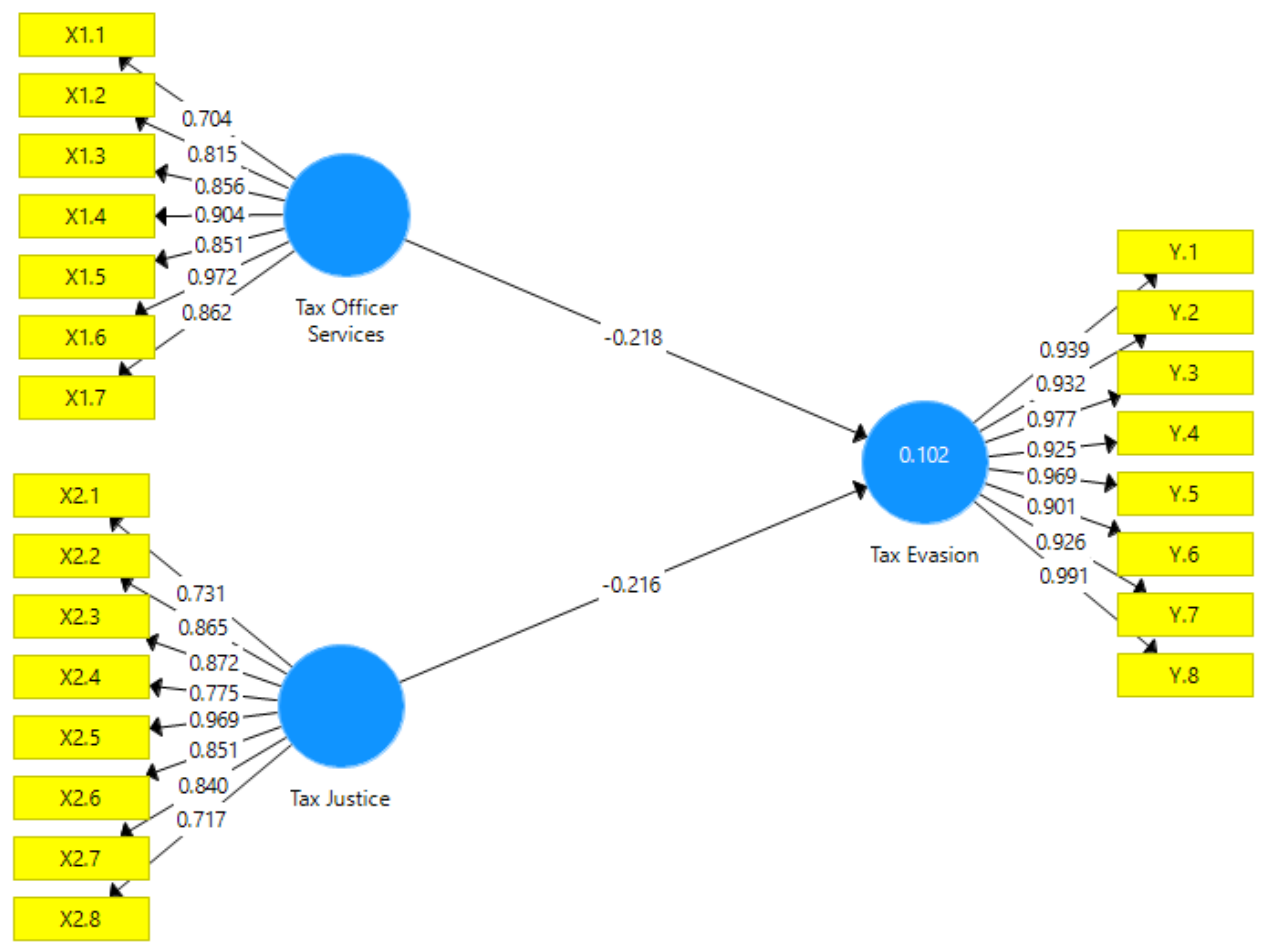

Source: (Data in SmartPLS has been proceed, 2019)

Based on the estimation results of the PLS model in the picture above, all indicators already have a loading factor value above 0.7 . The loading factor value for each indicator and the complete AVE value for each construct can be seen in the following table:

Table 4. Value of Loading Factor and AVE

\begin{tabular}{|c|c|c|c|c|c|c|}
\hline Variabel & Indikator & $\begin{array}{l}\text { Loading } \\
\text { Factor }\end{array}$ & $\begin{array}{l}\text { Cut Value } \\
\text { Loading } \\
\text { Factor }\end{array}$ & AVE & $\begin{array}{l}\text { Cut } \\
\text { Value } \\
\text { AVE }\end{array}$ & $\begin{array}{l}\text { Validitas } \\
\text { Konvergen }\end{array}$ \\
\hline \multirow{7}{*}{$\begin{array}{c}\text { Tax Officer } \\
\text { Services }\end{array}$} & $\mathrm{X} 1.1$ & 0.704 & 0.7 & \multirow{7}{*}{0.731} & \multirow{7}{*}{0.50} & valid \\
\hline & $\mathrm{X} 1.2$ & 0.815 & 0.7 & & & valid \\
\hline & $\mathrm{X} 1.3$ & 0.856 & 0.7 & & & valid \\
\hline & $\mathrm{X} 1.4$ & 0.904 & 0.7 & & & valid \\
\hline & $\mathrm{X} 1.5$ & 0.851 & 0.7 & & & valid \\
\hline & X1.6 & 0.972 & 0.7 & & & valid \\
\hline & X1.7 & 0.862 & 0.7 & & & \\
\hline \multirow[t]{4}{*}{ Tax Justice } & $\mathrm{X} 2.1$ & 0.731 & 0.7 & \multirow[t]{4}{*}{0.691} & \multirow[t]{4}{*}{0.50} & valid \\
\hline & $\mathrm{X} 2.2$ & 0.865 & 0.7 & & & valid \\
\hline & $\mathrm{X} 2.3$ & 0.872 & 0.7 & & & valid \\
\hline & $\mathrm{X} 2.4$ & 0.775 & 0.7 & & & valid \\
\hline
\end{tabular}




\begin{tabular}{|c|c|c|c|c|c|c|}
\hline Variabel & Indikator & $\begin{array}{l}\text { Loading } \\
\text { Factor }\end{array}$ & $\begin{array}{l}\text { Cut Value } \\
\text { Loading } \\
\text { Factor }\end{array}$ & AVE & $\begin{array}{l}\text { Cut } \\
\text { Value } \\
\text { AVE }\end{array}$ & $\begin{array}{l}\text { Validitas } \\
\text { Konvergen }\end{array}$ \\
\hline & $\mathrm{X} 2.5$ & 0.969 & 0.7 & & & valid \\
\hline & $\mathrm{X} 2.6$ & 0.851 & 0.7 & & & valid \\
\hline & $\mathrm{X} 2.7$ & 0.840 & 0.7 & & & valid \\
\hline & $\mathrm{X} 2.8$ & 0.717 & 0.7 & & & valid \\
\hline \multirow{8}{*}{ Tax Evasion } & Y.1 & 0.939 & 0.7 & \multirow{8}{*}{0.894} & \multirow{8}{*}{0.50} & valid \\
\hline & Y.2 & 0.932 & 0.7 & & & valid \\
\hline & Y.3 & 0.977 & 0.7 & & & valid \\
\hline & Y.4 & 0.925 & 0.7 & & & valid \\
\hline & Y.5 & 0.969 & 0.7 & & & valid \\
\hline & Y.6 & 0.901 & 0.7 & & & valid \\
\hline & Y.7 & 0.926 & 0.7 & & & valid \\
\hline & Y.8 & 0.991 & 0.7 & & & valid \\
\hline
\end{tabular}

Source: (Data in SmartPLS has been proceed, 2019)

The results of the PLS analysis in the table above, show the loading factor values of all indicators> 0.7 and AVE values for all constructs that have exceeded 0.5, which indicates that all indicators in each construct have met the required convergent validity criteria.

Determination Coefficient Test. Smart PLS calculates the output of R Square and Adjusted R Square as follows:

Table 5. Value of R Square

\section{R Square}

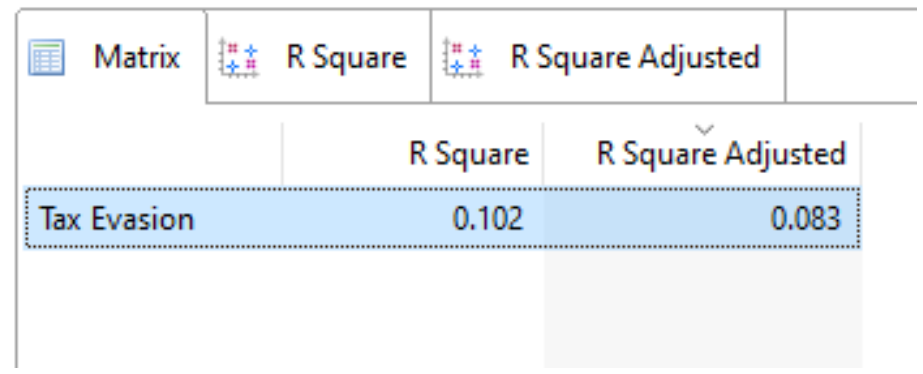

Source: (Data in SmartPLS has been proceed, 2019)

From the picture above it can be concluded that the Tax Officer Services and Tax Justice contributed to the occurrence of Tax evasion of 0.102 or $10.2 \%$ while the remaining $89.8 \%$ was explained by other variables not examined in this study.

The Goodness of fit Model Test. After fulfilling the validity and reliability of the construct at the outer model testing stage, the test continues on the Goodness of fit model testing. Fit the PLS model can be seen from the SRMR value of the model. The PLS model is stated 
to have met the criteria of goodness of fit model if the SRMR value $<0.10$ and the model declared perfect fit if the SRMR value $<0.08$.

Table 6. Table of Fit Model

\begin{tabular}{l|r|r}
\multicolumn{2}{l}{ Model_Fit } \\
\hline \multirow{2}{*}{ Fit Summary } & 粗 rms Theta & \\
\cline { 2 - 3 } & Saturated Model & Estimated Mo... \\
\hline \multirow{2}{*}{ SRMR } & 0.067 & 0.067 \\
\hline d_ULS & 1.242 & 1.242 \\
\hline d_G & 1.273 & 1.273 \\
\hline Chi-Square & 530.984 & 530.984 \\
\hline NFI & 0.833 & 0.833
\end{tabular}

Source: (Data in SmartPLS has been proceed, 2019)

From the results of the PLS model goodness of fit test shows the saturated model SRMR value of 0.067 as well as the SRMR value of the predicted model which has an SRMR of 0.067 . Because the saturated model SRMR and the predicted model are below 0.10 , the PLS model is declared perfect fit, so it is feasible to use to test the research hypothesis.

The Inner Model Test. Testing the inner model in this study includes the test of the significance of direct influence, and measurement of the effect of each exogenous variable on endogenous variables. All of these tests will be used to test the research hypothesis. Testing of Direct Effects. The direct effect significance test is used to test the effect of exogenous variables (Tax Services, Tax Justice) on endogenous variables (Tax evasion) H1: Tax officer services influence to Tax Evasion in listed company at KPP Kosambi Tangerang, H2: Tax justice influence to Tax Evasion in listed at KPP Kosambi Tangerang. The significance of exogenous variables for endogenous variables is if the $\mathrm{P}$ value is $<0.05$ and the $\mathrm{T}$ statistic is $>1.96$. whereas if the value of $\mathrm{P}$ Values $>0.05$ indicates that the exogenous variable does not have a significant effect on endogenous variables, the significance test can then be used to see the effect of exogenous variables on endogenous. The estimation results of the model as a reference to test the hypothesis in this study can be seen in the following figure: 
Figure 4. PLS Model Estimation Results - Bootstrapping

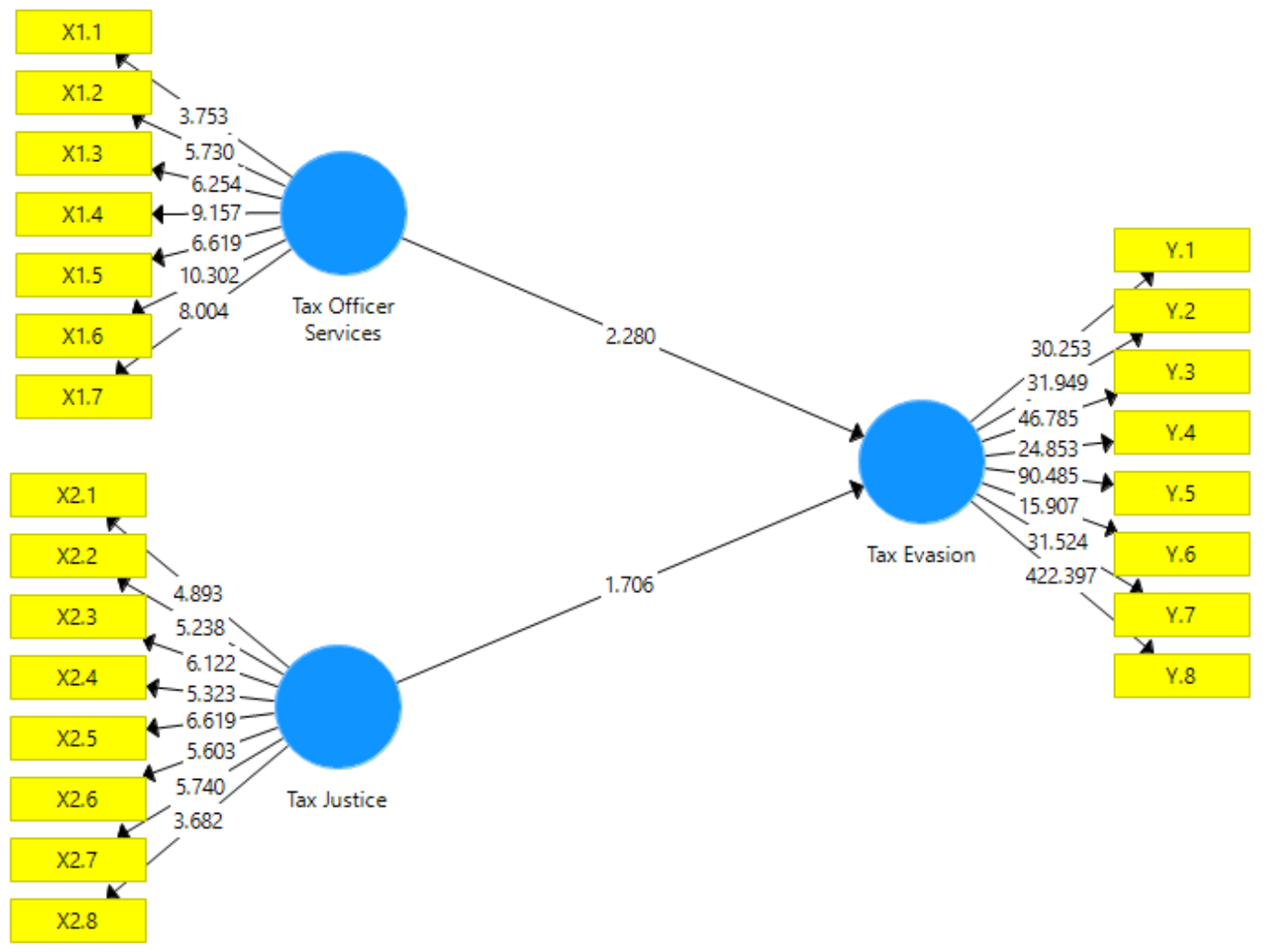

Source: (Data in SmartPLS has been proceed, 2019)

Based on the estimated results of the PLS model with the bootstrapping technique above, the $t$ value for the fiscal service variable is 2,280 over 1.96, while for the Tax Justice variable is 1,706 less than 1.96 . The complete significance test results can be seen in table below:

Table 7. Significance Test

\section{Path Coefficients}

\begin{tabular}{|c|c|c|c|c|c|c|c|}
\hline \multirow[t]{2}{*}{ Mean, STDEV, T-Values, P-Val... } & Confidence Inter & & 圂 Confidence & ntervals Bias Co... & Sample & Copy to Clipboard: & \multirow{2}{*}{$\begin{array}{c}\text { Excel Format } \\
\text { P Values }\end{array}$} \\
\hline & Original Sample $(0)$ & \multicolumn{2}{|c|}{ Sample Mean (M) } & \multicolumn{2}{|c|}{ Standard Deviation (STDEV) } & TStatistics (|O/STDEV|) & \\
\hline Tax Officer Services $->$ Tax Evasion & -0.218 & & -0.238 & & 0.096 & 2.280 & 0.023 \\
\hline Tax Justice -> Tax Evasion & -0.216 & & -0.234 & & 0.127 & 1.706 & 0.089 \\
\hline
\end{tabular}

Source: (Data in SmartPLS has been proceed, 2019)

From the results of testing using SmartPLS produced: The Tax Service Service variable has a value of 2,280 greater than 1.96 (T statistic $>$ of $\mathrm{T}$ table) and a $\mathrm{P}$ value of 0.023 is more than 0.05 , and the original sample value is -0.218 . This means that the hypothesis H1 (Fiscus Services affect tax Evasion) is received in a negative direction, while for the Tax Justice Variable has a value of 1,706 smaller than 1.96 (T statistic < from 
T table) and a P Value of 0.089 is more than 0.05 , and the original sample value is -0.216 . This means that H2 (Tax Justice affects Tax Evasion) is rejected.

Impact of Tax officer service to tax evasion. The result of research proven that tax officer services has negative influence to tax evasion. Getting worse down of services, so would be worse down to public awareness above tax regulation and would be greater up intention of tax-payer to embezzlement of tax/tax evasion. This matter has possibility taxpayer felt how worse of tax officer services so that they unwilling to pay their liabilities. Many kinds of worse of services by tax officer, such as: lack of experience in training and education in serving taxpayers, less of socialization and information, arrogance of tax officer, unwell governance of bureaucratic administration in another case, those are the reason for tax-payer do not obey about tax regulation so that impact to unwilling to pay tax liabilities. This condition accordance by result of research by (Mujiati et al., 2017 ) They declared that Taxpayers will obediently pay taxes if the services provided by tax officers are in accordance with their expectations, so that if the services provided do not meet their expectations, taxpayers will see that tax evasion actions are legal.

Impact of Tax Justice to Tax Evasion. The result of research proven that tax justice have not influence to tax evasion. This matter is contradictive with result of research by (Pratiwi and Prabowo, 2019) and (Kurniawati and Toly, 2014 ) however the results of this study are in line with research conducted by (Ardyaksa and Kiswanto, 2014) and (Friskianti and Handayani, 2014). They declared that tax justice influence to tax evasion. In this research the sample are the enterprise as tax-payer. Where as tax-payer they assumptive that there is not problem, is the tax will managed fairly or not ? And they assumptive also, is the tax officer will be wise and fair in their duties. This is in accordance with the planned theory of behavior which states that the perception of the ability to control behavior (perceived behavioral control), namely the tendency for someone to choose to do or not do something work even though there is no cause for the behavior to do the wrong action but, mandatory Taxable behavior requires doing things that are contrary to legal norms.

Impact of Tax Officer Services and Tax Justice to Tax Evasion. The result of research proven that tax officer services and tax justice are together influence to tax evasion. This matter has a possibility on come true if only tax officer services and tax justice had unperformed, so that it's impacted to tax-payer on tax evasion.

\section{CONCLUSION}

Conclusion. The result and studies of this research had conclude that: (1) Variable of tax officer services has negative influence to tax evasion. (2) Variable of tax justice has not influence to tax evasion.. Thus matter has a possibility to be: Tax-payer felt that the good service would be satisfy on them. The worse services would be disappoint on them. Taxpayer assumptive that disappointed at caused worse of services impact to unwilling to pay on their tax-liabilities. Otherwise, the worse service could be motivate tax-payer to tax evasion. 
Implications, The implication of the results of this study explains what factors can cause corporate taxpayers to be motivated to carry out tax evasion, and the results of this study can also be used as a reference for KPP Pratama Kosambi in improving services for corporate taxpayers and servants as to what should be improved so that Satisfaction level of taxpayers can increase. Good service will be able to prevent taxpayers from having the motivation to carry out tax evasion.

Limitations. limitations of this study are as follows: (1) The independent variables studied were limited to only two variables, Tax Officer Services and Tax justice. (2) The sample of this study is only limited to corporate taxpayers who are registered at the KPP Pratama kosambi Tangerang.

Suggestion.From the result and studies of this research, researcher suggest to: (1) For the next research: the next researcher should to add the scope of research by more usage variable or substitute by other variable that assumptive has high relation and more relevant to the topics, such as: taxing system and implementing IT in taxing. (2) For the Tax Officer/Representative of government: In serve on tax-payer, the tax officer should to implement the key success service performance or "service excellent way". Handling the tax-payer's objection by empathy and enthusiasm. So that tax-payer know the accordance between nominal in paid are same due at received nominal. And tax-payer could felt how necessary of tax. The tax officer must to implement the good profession ethics and transparency on governance as effort to minimize tax evasion and to avoid of its conspiracy.

\section{REFERENCE}

Ardyaksa dan Kiswanto. (2014). Pengaruh Keadilan, Tarif Pajak, Ketepatan Pengalokasian, Kecurangan,Teknologi dan Informasi Perpajakan terhadap Tax Evasion. Accounting Analysis Journal, Semarang.

Benk, Serkam and Tamer Budak. (2015). Perception of Tax Evasion as a crime in Turkey, Jurnal of Money Laundering Control.

Fallis, A. (2013). Pengaruh Keadilan, Sistem Perpajakan, Diskriminasi, Dan Kemungkinan Terdeteksi Kecurangan Terhadap Persepsi Wajib Pajak Mengenai Etika Penggelola. Journal of Chemical Information and Modeling.

Fatimah,Siti dan D. Kusuma Wardani. (2017). Faktor-Faktor yang Mempengaruhi Penggelapan Pajak di Kantor Pelayanan Pajak Pratama Temanggung, Jurnal Akuntansi Dewantara, Fakultas Ekonomi Universitas Sarjanawiyata Tamansiswa, vol. 1. No.1.

Friskianti dan Handayani (2014). Pengaruh Self Assessment System, Keadilan,Teknologi Perpajakan dan Ketidakpercayaan Kepada Pihak Fiskus Terhadap Tindakan Tax Evasion. Accounting Analysis Journal. Semarang.

Hartanti, Rina and Muhammad Nuryanto. (2019). Factors That Influence The Interest In Using Tax Consultant Services. Jurnal Akuntansi, Vol. XXIII, No.1.

Kurniawati, M. (2014). Analisis Keadilan Pajak, Biaya Kepatuhan, Dan Tarif Pajak Terhadap Persepsi Wajib Pajak Mengenai Penggelapan Pajak Di Surabaya Barat. Tax \& Accounting Review. Surabaya. 
Mardiasmo. (2018). Perpajakan Edisi Terbaru. Yogyakarta: Penerbit Andi

Mansor and Gurama. (2016). The Determinants Of Tax Evasion In Gambe State Nigeria, International Journal Of Economics and Financial Issue, Malaysia.

Mujiati, Rohmawati dan Ririn (2017). Determinasi Persepsi Mengenai Etika Atas Penggelapan Pajak (Tax Evasion). Riset Akuntansi Dan Keuangan Indonesia, Surakarta.

Oktaviani, Srimindarti dan Hardiningsih. (2018). Peran Religionsity Sebagai Pemoderasi Hubungan Money Ethics Terhadap Upaya Tax Evasion, Jurnal Akuntansi. Vol. XXII, No.1, Universitas Tarumanegara.

Permatasari, Inggrid, H. L. (2013). Minimalisasi Tax Evasion Melalui Tarif Pajak, (Studi Empiris pada Wajib Pajak Orang Pribadi di Wilayah KPP Pratama Pekanbaru Senapelan). Diponegoro Journal of Accounting. Semarang.

Priantara, Diaz. (2016) Perpajakan Indonesia, Edisi 3, Mitra Wacana media.

Pohan,Chairil anwar (2017). Pembahasan Komprehenshif Pengantar Perpajakan Teori dan Konsep Hukum Pajak, Jakarta, Mitra Wacana.

Pohan, Chairil Anwar (2015). Manajemen Perpajakan, Strategi Perencanaan Pajak dan Bisnis. Jakarta Gramedia.

Pratiwi dan Prabowo. (2019). Keadilan dan Deskriminasi Pajak Terhadap Penggelapan Pajak: Persepsi Wajib Pajak Orang Pribadi, AFRE Accounting and Financial Review.

Rifani, Mursalim dan Ahmad. (2019). Pengaruh Keadilan, Sistem Perpajakan dan Kulaitas Pelayanan Terhadap Penggelapan Pajak. PARADOKS: Jurnal Ilmu Ekonomi, Universitas Muslim Indonesia

Republik Indonesia, Undang-Undang Nomor 28 Tahun (2007) tentang Perubahan Ketiga atas Undang-Undang Nomor 6 Tahun 1983 tentang Ketentuan Umum dan Tata Cara Perpajakan.

Sugiyono (2017). Metode Penelitian Kualitatif: Untuk penelitian yang bersifat: eksploratif, enterpretif, interaktif, dan konstruktif. Bandung: Alfabeta

Sustainability, E. (2014). The Determinants of Tax Evasion in Pakistan-a Case Study of Southern Punjab. International Journal of Development and Economic Sustainability. Pakistan

Waluyo.(2013). Perpajakan Indonesia. Jakarta: Salemba Empat. 